\title{
Sen, Justice and the Private Realm of Dispute Resolution
}

"At the heart of the particular problem of a unique impartial resolution of the perfectly just society is the possible sustainability of plural and competing reasons for justice, all of which have claims to impartiality and which nevertheless differ from - and rival - each other. Let me illustrate the problem with an example in which you have to decide which of three children - Anne, Bob and Carla - should get a flute about which they are quarrelling."1 Each child in Amartya Sen's example has a reason why he or she should get the flute. Anne is the only one who can play it; Bob has no toys; and Carla spent time making the flute: utilitarian theory supports Anne, economic egalitarian theory supports Bob, and libertarian theory supports Carla. $^{2}$ Each basis to entitlement is valid and alone would be sufficient reason for an allocation. The point that Sen makes in using this 'three children and one flute' scenario throughout his treatise on justice is that each of the children have compelling arguments in support of their entitlement to the flute: one child's reason why he or she should possess it is as good as the next child's, and different resolutions could be effected that are equally valid and, dare the word be used, just. ${ }^{3}$

This conundrum offered by Amartya Sen forces a consideration of how to value which child should get the flute; or more pertinently for purposes of this paper, what is the just decision for these children? The answer seems to depend on the position that is taken about the definition of justice. Sen's approach to justice challenges the normative conception of justice flowing from state-sponsored, rulebased judicial institutions. Sen questions why an imposed decision such as one delivered by a judicial tribunal should result in justice whereas an agreement between the three children regarding their selection as to who is best worthy to

\footnotetext{
${ }^{1}$ Amartya Sen, The Idea of Justice (London: Penguin, 2009) at 12-3.

2 Sen, note 1 at 13-4.

${ }^{3}$ Sen, note 1 at $14-5$.
} 
receive the flute would not result in justice. ${ }^{4}$ It is this premise that Sen explores in his work, and it is his theories on justice that are applied in this paper to determine whether the private dispute resolution process of mediation can result in a just resolution for its participants. In other words, can the agreement reached consensually between parties through a mediation process result in justice for the parties as would an imposed decision delivered by a judicial tribunal?

\section{The Normative Landscape of the Mediation Process}

A normative conception of justice is particularly acute in the private dispute resolution field, and in particular, in relation to the mediation process. The presence of justice or the perceived lack thereof provides fodder for debate in the literature. Explorations of justice in mediation have tended to be positivist in nature or relying on a legal consciousness analysis. Genn and Fiss, for example, argue that there is no justice in private processes of dispute resolution, including mediation. ${ }^{5}$ For them, justice can be delivered only by state law through its juridical institutions, very much a Rawlsian conception. ${ }^{6}$ Others argue that there is some form of justice working in mediation such as popular, restorative or procedural justice, or access to justice, all of which offer a way to attach a conception of justice to the mediation

\footnotetext{
${ }^{4}$ Sen, note 1 at 396.

5 Hazel Genn, "What is Civil Justice For? Reform, ADR, and Access to Justice" (2012) 24 Yale J.L. \& Human. 397; Hazel Genn, Judging Civil Justice (Cambridge: Cambridge University Press, 2010); Hazel Genn, "Why the Privatisation of Civil Justice is a Rule of Law Issue", 36" F.A. Mann Lecture, Lincoln's Inn, 19 November 2012. Found at <http://www.laws.ucl.ac.uk/wp-content/uploads/2014/08/36th-F-A-Mann-Lecture19.11.12-Professor-Hazel-Genn.pdf>; Owen Fiss, "Against Settlement" (1984) 93 Yale L. J. 1073; Owen Fiss, "History of an Idea" (2009) 78 Fordham L. Rev. 1265. An interesting point here is the assumption made by these scholars that legal institutions deliver justice. See also, Symposium - Against Settlement: Twenty-five Years Later" in (2009) 78 Fordham L. Rev. 1117 and articles following for commentary regarding Fiss's views. 6 John Rawls, $A$ Theory of Justice (Boston: Harvard University Press: 2009); Sen, note 1 at 78-85, 135. In fact, a Rawlsian analysis is applied to mediation in Lola Akin Ojelabi, "Mediation and justice: an Australian perspective using Rawls' categories of procedural justice" (2012) 31(3) Civil Just. Q. 318 which examines Rawls' views of procedural justice and argues that mediation delivers procedural justice within a Rawlsian framework. In this paper, the exploration is of substantive justice as described above.
} 
process. ${ }^{7}$ These forms of justice do not satisfy the contention that justice can be delivered only through the application of normative rules by judicial institutions of state. While this remains an area of controversy within the mediation scholarship, the relevance of an exploration into the ability of mediation to deliver justice and the nature of that justice lies in the positioning of mediation in civil justice. Mediation is no longer merely an informal dispute resolution process - it is often part and parcel of an overarching civil justice system in which settlement has become a key objective. ${ }^{8}$

This institutionalisation of mediation in civil justice supports Abel's assertion that the state has moved into the private realm of dispute resolution by encouraging

${ }^{7}$ See generally, Sally Engle Merry \& N. Milner, eds., The Possibility of Popular Justice: A Case Study of Community Mediation in the United States (Ann Arbor: University of Michigan Press, 1993); Patricia Ewick \& Susan S. Silbey, "Conformity, Contestation, \& Resistance: An Account of Legal Consciousness" (1992) 26 New England L.R. 731; Patricia Ewick \& Susan S. Silbey, The Common Place of Law (Chicago: The University of Chicago Press, 1998); S. Blake, J. Browne and S. Sime, A Practical Approach to Alternative Dispute Resolution (Oxford: Oxford University Press, 2012); M.S. Herrman, ed., The Blackwell Handbook of Mediation: Bridging theory, Research and Practice (Oxford: Blackwell, 2006); Colleen M. Hanycz, "More access to less justice: efficiency, proportionality and costs in Canadian civil justice reform, (2008) 27 Civil Just. Q. 98. For an examination of legal consciousness through ethnographic data, see Elizabeth A. Hoffman, "Legal Consciousness and Dispute Resolution: Different Disputing Behavior at Two Similar Taxicab Companies" (2003) 28 Law \& Soc. Inquiry 691. 8 In England and Wales, the integration occurs through the Civil Procedure Rules ("CPR"), 1998 SI 1998/3132, rules 1.1(1), 1.4(1), 1.4(2), 26.4(1), 44.2 and 44.4 (currently, as amended by The Civil Procedure (Amendment) Rules 2017). See also, Simon Roberts, (2009) "'Listing Concentrates the Mind': the English Civil Court as an Arena for Structured Negotiation" (29) Oxford Journal of Legal Studies 457. Further afield there is the EU Directive 2008 which requires EU member states to encourage the use of mediation for cross-border disputes in civil and commercial matters. While the focus of the Directive is on cross-border disputes, the impact of the Directive has been the implementation of the Directive across member states for domestic as well as cross-border purposes (Directive 2008/52/EC of the European Parliament and of the Council of 21 May 2008 on certain aspects of mediation in civil and commercial matters at <http://data.europa.eu/eli/dir/2008/52/oj>); see Giuseppe De Palo \& Mary B. Trevor, EU Mediation Law and Practice (Oxford: OUP, 2012) in which a review of mediation and civil justice in various countries of Europe is explored. See also, Jacqueline M. Nolan-Haley, "Is Europe Headed Down the Primrose Path with Mandatory Mediation?" (2012) 37 N.C.J. Int'l L. \& Com. Reg. 981 which examines the introduction of mandatory mediation regimes in civil justice. 
private disputing processes. ${ }^{9}$ As such, the issue of whether mediation delivers justice is an important one for proponents and critics alike. It is a debatable one, as noted above, and dependent on the form of justice at issue. The search for justice in mediation is stymied by the manner in which the issue is often framed by a legal view of justice, where justice is based on positivist theories of law. In that framework, given its nature as a private consensual resolution process, the argument that mediation cannot deliver that form of justice is not surprising. Such a framework, however, offers too restrictive a worldview.

\section{Sen's Justice Framework for Mediation}

This paper seeks to challenge the current positivist paradigm through which mediation's ability to deliver justice is assessed. It explores the question whether the mediation process can deliver a substantive form of justice that is comparable to the justice delivered by the juridical institution. It does so through Sen's conception of justice and more particularly, its elements of objective reasoning, rational choice and freedom of choice. It will conclude that, while mediation may not in its current form deliver a substantive form of justice, it has the possibility of achieving it. It is this possibility, which will elevate mediation's value as a dispute resolution process.

Amartya Sen's theory of justice allows this possibility. Through the integration of (i) objective reasoning, (ii) rational choice and (iii) freedom of choice as forming the basis for a just decision, Sen's theory of justice rejects the positivist view of reliance on the just institution, and in particular, the Rawlsian construction of ideal justice. ${ }^{10}$ These three elements create a framework that is pluralistic in nature, offering a view of justice that is not dependent on legal conceptions nor ideal notions of justice

\footnotetext{
${ }^{9}$ Richard L. Abel, 'The Contradictions of Informal Justice', in Richard L. Abel (ed.) The Politics of Informal Justice, Volume 1: The American Experience (New York: Academic Press, 1982). For discussion about mediation's place in civil justice and an examination of both government policy and judicial views, see Debbie De Girolamo, "Rhetoric and Civil Justice: A Commentary on the Promotion of Mediation without Conviction in England and Wales" (2016) 35(2) Civil Just. Q 162.

10 Sen, note 1 at 78-86.
} 
yet offering a form of justice that is substantive in nature. It takes a wholistic approach where restrictive categories of description are eschewed in favour of an all-encompassing theory of justice. As Twining states, Sen is not interested in the ideals of justice, but is more interested in what can be achieved in the real world. ${ }^{11}$ It offers an opportunity to move away from the law in the search for justice in mediation and to answer the conundrum described above: why should the judge's decision be just but not the decision of the actors to the dispute?

\section{Data Collection of the Mediation Process}

This examination of the mediation process and its ability to deliver justice relies on ethnographic data obtained about the mediation process through a participantobservation research project reported in an earlier work where the author was a participant observer at a British organisation offering conflict resolution services (the Organisation). ${ }^{12}$ An ethnographic study is one where 'thick description' of data collection leads to an interpretative exercise of the phenomenon observed..$^{13}$ It is not the collection of data for quantitative purposes, such as attempting to establish a preponderance of evidence. Rather, it exposes patterns of action and structures for qualitative study. Further, the field is often not entered with a specific purpose. Indeed, the original project was entered to seek what Malinowski refers to as the imponderabilia of life: “...there is a series of phenomena of great importance which cannot possibly be recorded by questioning or computing documents, but have to be

\footnotetext{
11 William Twining, "Review Essay: Responding to Globalization by Rafael Domingo" (2011) 49 Osgoode Hall L.J. 353 at 69.

12 To preserve the anonymity of the participants of the mediation process explored in this paper as well as the Organisation itself, the Organisation is not named and will hereinafter be referred to as the Organisation. Much of the description of the ethnographic method for the collection of the data for this paper is taken from Debbie De Girolamo, The Fugitive Identity of Mediation: Negotiations, Shift Changes and Allusionary Action (Abingdon: Routledge, 2013) at 34-44. For a more fulsome description of the ethnographic methodology, see chapters 1,2 and 3 therein.

${ }^{13}$ Clifford Geertz, The Interpretation of Culture (New York: Basic Books, 1973) at 16, 20.
} 
observed in their full actuality. Let us call them the imponderabilia of actual life."14 In other words, there was no specific search for justice in the data as it was being observed. It is for purposes of this paper that the ethnographic data has been reviewed again for what it says about the mediation process in relation to justice. The data herein reports on the lived experience of the participants to the process.

Over a continuous period of 12 months in 2006 and 2007, the author attended 38 civil and commercial mediations conducted through the Organisation as a participant-observer. The mediations attended were randomly selected subject to three conditions: the author was available on the date the mediation was scheduled, the mediation involved a civil or commercial dispute, and the mediation was within a two-hour train ride radius from London, England. The identity of the mediator was not relevant in this random selection process.

The mediators observed were mediators who had been accredited by the Organisation after successful completion of the Organisation's training programme of 40 hours including lecture, role-play study and assessment. ${ }^{15}$ They were trained according the Organisation's mediation model, which includes (i) the preparation phase involving the initial contact to mediate and preliminary communication with the parties, dealing with documentary exchange and learning about the history of the dispute; (ii) the opening phase dealing with the arrival of parties at the mediation, private premediation meetings with the parties, and the opening joint sessions at which the parties make opening statements; (iii) the exploration phase involving private meetings and/or joint sessions the aims of which are to build relationships and trust, information exchange, clarification of issues and interests and 'preparing the way for settlement negotiations'; (iv) the bargaining phase

\footnotetext{
14 Bronislaw Malinowski, Argonauts of the Western Pacific (Long Grove: Waveland, 1984 Edition) at 18.

15 These accreditation standards reflect the current standards required by the Civil Mediation Council, a not-for-profit organisation seeking to promote mediation in the UK including high standards and good practice among mediation service providers and individual mediators, and they are typical of other mediation training programmes; see at $<$ http://www.civilmediation.org/about-cmc $>$.
} 
during which the mediator facilitates movement by working creatively, negotiating, overcoming barriers, coaching the parties, and 'shaping' the settlement; and (v) the concluding phase dealing with the finalisation of the settlement agreement. ${ }^{16}$ This mediation framework is used by other organisations for civil and commercial mediations as well as for court-connected mediations; as such, it is a common one that continues to be relevant today. ${ }^{17}$

The observed mediators were a mix of practicing and non-practicing lawyers (reflective of the majority), and other non lawyer professionals having particular subject-matter expertise. They were senior and experienced mediators, and were members of the Organisation's panel of mediators subject to the Organisation's code of conduct for mediators. ${ }^{18}$ The mediations involved civil and commercial disputes, often at some stage of litigation or contemplated litigation. ${ }^{19}$ Additionally, during most of the mediations, parties in dispute attended with legal counsel.

\footnotetext{
16 De Girolamo, note 12 at 68-71. As stated in the original work regarding this ethnographic project, the Organisation's training manual sets out the mediation philosophy of the Organisation and provides the basis for accreditation. The manual is on file with the author. This framework is a typical one: see Christopher Moore, The Mediation Process: Practical Strategies for Resolving Conflict (San Francisco: Jossey-Bass, 1996) at 66-7. 17 See for example, mediations conducted by JAMS in the United States $<$ https://www.jamsadr.com/mediation-defined/> and $<$ https://www.jamsadr.com/mediation-guide/> and in England, In Place of Strife, The Mediation Chambers <http://www.mediate.co.uk/sector/civil-and-commercial/> and for mediations under the Ontario Mandatory Mediation rule, see C.M. Hanycz, "Through the Looking Glass: Mediator Conceptions of Philosophy, Process and Power" (2004-2005) 42 Alta. L. Rev. 819 which provides a discussion on the practice in court-connected mediations and Sue J. Prince, "Mandatory Mediation: the Ontario experience" (2007) 26 Civil Justice Quarterly 79.

18 The Organisation did and continues to subscribe to a code of conduct for its mediators and has a complaints process.

19 While the mediations were not conducted within a court imposed mandatory mediation scheme, many were conducted within the litigation context and thus were subject to the rules of court which require parties to consider engaging in settlement discussions including $\mathrm{ADR}$, with an unreasonable refusal to engage in mediation subject to cost sanctions: see Civil Procedure Rules ("CPR"), 1998 SI 1998/3132, rules 1.1(1), 1.4(1), 1.4(2), 26.4(1), 44.2 and 44.4 (currently, as amended by The Civil Procedure (Amendment) Rules 2017); Halsey v Milton Keynes General NHS Trust [2004] 1 WLR 3002.
} 
The author attended these mediations primarily as an independent researcher and also as an assistant mediator. Parties were aware of the purpose of the author's attendance as a researcher. The label of assistant mediator is somewhat of a misnomer as very minor administrative tasks were performed in this role such as taking notes and acting as a sounding board to the mediator during private times. The lead mediator had full responsibility for the conduct of the mediation. Detailed notes were taken continuously throughout the process about the process, about what parties said during the process, their gestures, and their behaviour. As this was an ethnographic endeavour, there were no guidelines to follow in determining what to note - the pen rarely stopped. The role of observer permitted the author to step back from the process in order to see the process. ${ }^{20}$

Sen's approach to justice fits well with the ethnographic enterprise, where parochialism is shed for an expansive, creative approach to investigation. It is justice as revealed by the data and conceived by Sen that provides the focus for this investigation. The aim is two-fold: to change the justice narrative from one of restrictive normative rules to expansive pluralistic conceptions, and correspondingly, to change the mediation narrative as to expectations surrounding its ability to deliver justice.

\section{The Mediation Process and Sen's Idea of Justice}

\section{(a) Introduction to Sen}

\footnotetext{
20 The importance and separation of the observer from a participant role became specifically evident when, during one mediation, the lead mediator took ill and the parties requested that I continue the mediation (as I was also a trained mediator). From the moment that I laid down my pen as observer and became lead mediator, I was no longer able to observe the 'imponderabilia of life' as Malinowski would say. This emphasised the need to observe mediations as one outside the process in order to see into the process. Once working as mediator, the focus was on the dispute, the parties and the assistance the parties required. The luxury of focusing on what was occurring during the process for research purposes was lost.
} 
Amartya Sen rejects the notion of ideal justice premised on the just institution, what he refers to as transcendental institutionalism. ${ }^{21}$ Sen pits his theory of justice against that of Rawls who talks about societal institutions as being the source of ideal justice. ${ }^{22}$ Sen says that, for Rawls, political and societal institutions of the sovereign state provide justice. ${ }^{23}$ Such theory invokes the social contract of rules and arrangements for the attainment of justice. Justice is the product of the legal system through its courts and legal rules, as established by the state founded on the social contract.

The Sen theory, on the other hand, focuses on social realisations and human lives; it is one of social choice. ${ }^{24}$ Sen's view is based on the practicalities of human life and a recognition of the plurality of choices and outcomes. Most importantly, it is a view that is not premised on law: it rejects the institution, including its rules and actors. In other words, justice is not juridical in nature: it is not about the law nor what the law determines is just.

Neither, however, does Sen descend to a popularist view of justice, which has equally been the focus of justice arguments within the private realm of dispute resolution; he rejects the notion of popular justice just as he rejects the notion of institutional justice. ${ }^{25}$ Using the experience of pain and medical policy as an example to support his rejection of popular justice, Sen illustrates the way in which subjective views are not helpful to wellbeing: when people are in pain one cannot measure the pain experienced. Further, if people are experiencing pain and do not

\footnotetext{
21 Sen, note 1 at 410; See also, Amartya Sen, "Symposium on the Idea of Justice: A Reply" (2011) 43 Rutgers L.J. 317 for further discussion by Sen of various issues arising from his theory. The symposium also presents numerous commentary on Sen's theory of justice. 22 Sen, note 1 at 25.

23 Sen, note 1 at 78-80.

${ }^{24}$ Sen, note 1 at 410-412.

25 Institutional justice provides the substantive model of justice, which forms the basis for the various critiques of informalism and the need to have judge-made decisions to achieve justice. See Genn and Fiss, note 5; See Sen, note 1 at 274 \& 284-286 for this rejection of happiness as being a marker for justice, using the pain and medical policy example that follows.
} 
articulate this state of being, it does not mean they are not in pain, but it does mean that doctors cannot apply medication to lessen the pain. Sen says there are many factors that may limit the decision on whether one feels pain or whether to articulate experiencing pain such as culture, education, and custom; merely because one does not feel or articulate pain does not mean there is no pain. As a result, one cannot rely on the self-assessment of pain by an individual as a determinant for setting medical policy.

For Sen, a subjective evaluation of people's wellbeing cannot be a standard for justice (not that he uses the word here); he refers to pain, pleasure and happiness as being subjective standards which are irrelevant in the determination of the wellbeing of society as a whole. ${ }^{26}$ Arguably, this applies to his theory of justice: subjective views are coloured by people's experiences, their culture, and their customs and cannot be translated into decisions which advance justice claims. Individuals become acclimatised to deprivation, accepting injustices as normal; therefore, subjective views cannot be markers of justice. ${ }^{27}$

In Sen's conception, justice is objective, impartial and rational. It is also plural in its recognition of the diversity of values espoused by individuals and as such, it is evolutionary and not decisive. ${ }^{28}$ It does not rest on juridical conceptions of justice or on the personal satisfaction stories of actors. For Sen, through objective reasoning, rational choice and freedom of choice, a good agreement can be reached in terms of what he refers to as 'the reasoned judgment of justice'. ${ }^{29}$ These elements are not one-dimensional: objective reasoning needs a degree of impartiality, rational choice requires sustained reasoning, and freedom of choice requires capability and fairness of process.

\footnotetext{
26 Sen, note 1 at 286 .

27 Sen, note 1 at 274 .

28 Sen, note 1 at $89,110,200 \& 125$.

${ }^{29}$ Sen, note 21, "Symposium on the Idea of Justice: A Reply" at 325.
} 


\section{(b) The Mediation Process}

How then is this relevant to mediation and the quest for justice in the process? The nature of the mediation process differs from that of the civil adjudicative process, which is a rule-based, public and institutional process of decision-making by an arbiter selected by the state. Mediation is a private self-determinative process, where a third party is invited into the process by the parties to assist them to achieve a resolution of their dispute, the responsibility for which rests solely with the parties in dispute. In mediation, there is a convergence of rules and process on one hand and structures and processes on the other hand. First, rules provide the basis for claims that create the dispute and are used to influence outcome. Outcome, however, is dependent on social interaction that occurs during the process. Second, there is also the convergence of structure and process: mediation offers a structure of dispute resolution processing and operates within the larger societal structure of a rule-centered juridical institution. ${ }^{30}$

Mediation is institutional in nature where rules, process and structure collide within a civil justice paradigm. It is this nature of mediation, both as an institution itself and often situated within a state juridical institution that creates an expectation that mediation delivers justice, triggering a debate as to whether it does deliver justice, and if so, in what form. Institutional and thus ideal justice is equated to third-party decision-making in the neutral and open forum of a state court. Mediation is consensual party-led decision-making in a private forum and thus arguably not capable of delivering such justice. ${ }^{31}$ The reliance on legalism, however, is too

\footnotetext{
30 This convergence has been discussed in prior work: see De Girolamo, note 12 at 15-16, and Debbie De Girolamo, "Seeking Negotiated Order Through Mediation: A Manifestation of Legal Culture?" (2012) 5(2) Journal of Comparative Law 118 at 122-123,.

31 This is all by way of Rawls and which arguably forms the foundation for the positivist view of justice: see Sen's description of the Rawlsian construct at note 1 at 52-74. Sen also refers to Rawls in his later commentary about his theory: for example, see Amartya Sen, "Economics, Law and Ethics" in Reiko Gotoh \& Paul Dumouchel (eds.) Against Injustice: The New Economics of Amartya Sen (Cambridge: Cambridge University Press, 2009) 39 at 4752; Amarty Sen, "A Response" (2014) 5(2) Jurisprudence 385 at 386, 390, 394, 399; Sen,
} 
limiting. To explore justice through such a lens will inevitably lead to a conclusion that mediation does not provide substantive justice given the nature of its process as a consensual, private one, and the fact there is no third party decision-maker. Sen's theory, however, offers the mediation process the possibility of justice by moving the discussion beyond a Rawlsian model of the just institution and offering a conception of justice that is both substantive and non-juridical. This will be explored through the application of Sen's three elements to the mediation process, analysed through ethnographic data.

\section{Sen's Three Elements and Their Application to the Mediation Process}

\section{(a) Objective Reasoning}

Objective reasoning, says Sen, requires an open mind about information, reflection, interaction and debate. ${ }^{32}$ Debate must occur where the perspective of others is received and acknowledged. ${ }^{33}$ On a macro level, Sen refers to this element as one of public reasoning: "Public reasoning is so important in the approach I am trying to present, that to make room for it as a valued ability of a group of people - to speak to each other, to discuss pros and cons, to scrutinize together - must be very central."34 Dialogue through reasoned communication is one element of objective reasoning. The reasoned encounter must occur on an impartial basis. It is to the impartial outsider that Sen turns to, fueled by a need to move away from parochial values and understandings because they prevent proper assessments of justice. Justice, according to Sen, cannot come from narrow conceptions of perspective.

note 21, "Symposium on the Idea of Justice: A Reply" at 321-324. Contrary to this assertion, recall Ojelabi, note 6, who speaks in terms of Rawls and procedural justice, which is not the form of justice at issue in this paper.

32 Sen, note 1 at 40,49 .

33 Sen, note 1 at 337,162 \& 88.

34 Sen, note 21, "Symposium on the Idea of Justice: A Reply" at 334; see also, Amartya Sen, "Ideas of justice: a reply" (2013) 16(2) Critical Review of International Social and Political Philosophy 305 at 311 where Sen says that a theory founded on public reasoning means that people will be influenced by how they see themselves and others; see also, Sen, note 1 at 31-51. 


\section{(i) Discursiveness}

Communication and dialogue are important elements for the objective reasoning criteria of Sen's theory of justice: in particular, they require people to be openminded about information, to interact with others, to debate and to reflect, all suggesting a discursive quality to the formulation of objective reasoning. When one looks at the process of mediation, these characteristics are evident: all parties discuss their positions and interests during the initial joint session; parties tell their individual stories to the mediator in private meetings; mediators relay information and give advice to the parties; and parties interact throughout the process. ${ }^{35}$

For mediators, "mediation is the opportunity to hear what the other side is telling his client; there are two sides to every story; the same facts yield different views and to hear the views is quite important."36 Furthermore, the private meeting is for dialogue - to air things that parties did not want to say to the other, but wanted to say to the mediator. ${ }^{37}$ Mediators make clear to the parties at the beginning of the mediation session to "make sure you have your say; it is really important for you to have your say...[and] hear what they have to say and for you to know what you need." 38 While mediators may not believe that solicitors will agree on the issues, the exchange between parties is important "because clients need to know the other side's case."39 Another says, "We learned a lot."40 For the mediator in that case, face-to-face communication is key: "Sometimes lawyers come here hating each other and that, sometimes, correspondence is so bad that they would not want to

\footnotetext{
35 This is confirmed not only by the ethnographic data, but also the literature on the mediation process; see notes 16 and 17 for references to the literature..

36 Mediator from Case 10 at 10-5; see also mediator from Case 14 at 14-47.

37 Interview with mediator from Case 12 at 12-111.

38 Mediator from Case 13 at 13-11.

39 Mediator in joint session in Case 10 at 10-16.

40 Defendant from Case 13 at 13-53.
} 
place it before a judge and then they come to the mediation and are civil. It is the social act that is sometimes necessary." 41

One mediator talks about the mediator role: "[The] key skill of [the] mediator is to put himself in the shoes of parties and do this to enable parties to do this too; if you could get the parties to view the dispute through the eyes of the opponent it is hard to be in dispute and it helps to settle".42 Another mediator talks to the parties about the need to "have a debate while together; to get it out on the table." 43 Another tells the party that this is the "one chance to eyeball them before court. Take advantage of it and say what you want. Be commercial, constructive. Get it off your chest."44 For one party, there was no prejudice in "coming here today to listen to what you [the opposing party] have to say and come to resolution and if it is not to our satisfaction, we will take further steps." ${ }^{45}$ One counsel, after setting out what is important to his client, says to the other before discussing legal positions: "I need to go through [this] so it's not palm tree justice - I am going through the building blocks". 46

All participants in the mediation process, including mediator, disputants and legal representatives have the opportunity to talk about the dispute. This is seen both subjectively in their articulated views and objectively through the interactions that occur during the process. The ethnographic data shows that positions are bantered about; interests and motivations are discussed; facts are relayed; and evidence is challenged. It is all about discursive social interaction around a table. In mediation, decision-making occurs on the basis of what each party knows in relation to the

\footnotetext{
41 Mediator from Case 13 at 13-53.

42 Mediator interview from Case 13 at 13-76.

43 Mediator from Case 28 at 28-1.

44 Mediator from Case 9 at 9-9.

45 Claimant solicitor from Case 15 at 15-9.

46 Claimant counsel from Case 21 at 21-16.
} 
dispute. As one mediator says to a defendant: "As you get more and more information, the better able you are to judge what is the right thing to do." ${ }^{47}$

Does this social interaction of the mediation process meet the criteria offered by Sen? Is there enlightenment from divergent views? Is there comparative analysis? Are there social realisations? Sen speaks of the need for the assessment of justice to occur through interactive dialogue. In his formulation of justice, Sen speaks to the openness of decision-making, which is not reliant on institutional rules and actors. ${ }^{48}$ For Sen, it is important that parties talk to one another, to learn from others, to consider the other's perspective so as to make adjustments to perceived alternatives and their rankings, and thus be able to reach a "reasoned judgment of justice". ${ }^{49} \mathrm{We}$ see in the shape of the mediation process and through its actors' voices that mediation seeks enlightenment from divergent views, offers comparative analysis and provides social realisations. Talk, talk and more talk is a staple of the process, 50 meeting Sen's criteria in this regard.

Discursiveness alone, however, is not enough to establish the first element of objective reasoning; the second, 'impartiality' needs now to be considered.

\section{(ii) Open Impartiality}

For Sen, parochial views must be overcome for justice to be achieved. Personal views are insufficient to construct justice. He says: "Our entire understanding of the world, it can be argued, is thoroughly dependent on the perceptions we can have

\footnotetext{
47 Mediator to defendant team in Case 10 at 10-5.

48 Sen, note 1 at 337.

49 Sen, note 21, "Symposium on the Idea of Justice: A Reply" at 325.

50 Echoes here of the Arusha who say of their attempts to resolve matters through social interaction: "We discuss and discuss that matter (in dispute) and then we agree. When we agree, that is the end."; Philip H. Gulliver, Social Control in An African Society: A Study of the Arusha: Agricultural Masai of Northern Tanganyika (London: Routledge, 2000 edition) at 234.
} 
and the thoughts we can generate, given the kind of creatures we are."51 In other words, we depend on our human capacities and an understanding of the world based on our experiences. However, this does not mean that we cannot expand beyond them. Sen's anti-parochial voice offers the opportunity to move beyond what he sees to be positional objectivity. It is the perspective of the outsider that is required to ensure the implications of actions or inactions are fully understood. Sen refers to this requirement as 'open impartiality'. 52 Initially, it is not clear whether Sen requires an impartial judge for this requirement. ${ }^{53}$ Given his position on transcendental institutionalism, however, it is unlikely that Sen would require such a figure to be central to his theory of justice. Judges are institutional actors and Sen has moved away from reliance on the just institution. Given Sen's propensity against the social contract theory of the just institution while requiring open impartiality, it would seem that the outsider is not an institutional judicial voice; it is an anti-parochial voice. The anti-parochial voice comes from an outsider, a person who is outside the community and who helps to expand our thinking about the way we see and experience things. ${ }^{54}$ Sen refers to this as the requirement of open impartiality.

As regards the mediation process, Sen's outsider is arguably found in the persona of the mediator. In mediation, the parties make decisions based on their view of the case as enlightened by the mediation process. As noted by ethnographic data, the mediators portray themselves as a neutral and impartial observer and as an outsider to the parties. Specifically, we see that they have regard to their 'neutral' function as having no interest in the dispute and no opinion ${ }^{55}$; not favouring either

\footnotetext{
51 Sen, note 1 at $169-170$.

52 Sen, note 1 at $123,130,144 \& 405$.

53 Sen, note 1 at 401.

54 Sen, note 1 at 123-130.

55 Mediator to claimant in Case 11 at 11-11 and 11-14; See also mediator interview, Case 12 at 12-104; Mediator in Case 13 at 13-19; Mediator to parties in Case 33 at 33-5 and during mediator interview in Case 33 at 33-56.
} 
party; ${ }^{56}$ or being impartial..$^{57}$ They see themselves sitting outside of the dispute, forcing the parties to consider objective views of their positions. They portray themselves as the dispassionate voice or the disinterested bystander. As one mediator states, “Mediation enables the neutral to reflect on their [the parties'] interests." 58 These self-reflexive views of mediator operating as impartial third party facilitating the dialogue between the parties and positioning them towards resolution are generally supported in the mediation literature. Evident in many definitions of this mediated process is the description of the third party intervener as being neutral, impartial or independent, having no interest in the parties, the dispute or its outcome. ${ }^{59}$ Some argue that the mediator must be independent, impartial and without bias. ${ }^{60} \mathrm{He}$ is there to assist the parties in their negotiation as a facilitator in what might be described as an anodyne manner. ${ }^{61}$

56 Mediator in Case 13 at 13-19; Mediator to the claimant in Case 23 at 23-2; Mediator to all parties in joint session in Case 33 at 33-7.

57 Mediator to the responding party in Case $1 \mathrm{~A}$ at $1 \mathrm{~A}-4$.

58 Mediator interview in Case 13 at 13-77.

${ }^{59}$ In the literature, the intervener is often described as neutral, impartial or independent. See for example, Christopher W Moore, The Mediation Process: Practical Strategies for Resolving Conflict (San Francisco: Jossey-Bass, 1996) at 51-53 \& 197-198; Michael D Lang \& Alison Taylor, The Making of a Mediator: Developing Artistry in Practice (San Francisco: Jossey-Bass, 2000) at 161-162 \& 179-181; Susan Nauss Exon, "The Effects that Mediator Styles Impose on Neutrality and Impartiality Requirements of Mediation" (2007-2008) 42 USF L Rev 577; Marian Roberts, Developing the Craft of Mediation: Reflections on Theory and Practice (London: Jessica Kingsley Publishers, 2007) at 69; Simon Roberts and Michael Palmer, Dispute Processes: ADR and the Primary Forms of Decision-making (Cambridge: Cambridge University Press, 2005) at 197; Blake, Browne \& Sime, note 7 at 177.

60 See Stulberg who suggests that justice demands a mediator be neutral as he considers mediation is "a process for displaying and promoting justice". In his view, a neutral mediator is desired by the parties. See Joseph B Stulberg, "Must a Mediator be Neutral? You'd Better Believe It!" (2012) 95 Marq L Rev 829 at 829-830 \& 834. Further it is common to find requirements of neutrality, impartiality and/or independence in various mediator codes of conduct: see for example, the European Code of Conduct for Mediators, section 2 which speaks to independence and impartiality (see at $<$ http://ec.europa.eu/civiljustice/adr/adr_ec_code_conduct_en.pdf $>$ ); ICC Mediation Rules, article 5.3 where impartiality and independence are required of mediators (see at < https://iccwbo.org/dispute-resolution-services/mediation/mediation-rules/\#Article_7>); JAMS Mediator Ethics Guidelines, section 5 which require impartiality of mediators (see at < https://www.jamsadr.com/mediators-ethics/>); Rule 24.1.02 of the Ontario Civil Procedure Rules, R.R.O. 1990, Reg. 194 under the Courts of Justice Act, R.S.O. 1990, c. C.43, 
The data on this point however says otherwise, yet interestingly, provides additional support for the concept of the Sen outsider via a different iteration from this self-reflexive view by mediators about their perceived neutrality or impartiality. The data discloses active mediators who evolve through multiple identities during the course of the mediation process. Through these identity shifts, the mediator takes on opposing party voice and advisor voice in addition to his or her facilitator voice, all adding distinct outsider views to the process. ${ }^{62}$ Arguably, these identities provide a fortified societal voice: we have the third party who has been invited into the dispute taking on more than a perceived third party 'neutral' role and actively participating in the dispute from many perspectives. Traditional concepts of impartiality or neutrality expected from mediators as described in the literature (as earlier noted), may arguably be lost as a result of these interventions. However, for purposes of Sen's justice framework and the concept of 'open impartiality', these evolving identities serve to strengthen this view of mediator as outsider. The evolving identities push the parties to consider all aspects of their position and to move beyond parochial boundaries they have established for their dispute.

The mediator voices, therefore, take the dispute beyond the boundaries set by its actors. As Sen states, the impartial spectator is a "device for reasoned self-scrutiny"

which mandates mediation in civil justice describing mediation as a process involving a neutral third party who facilitates parties with the resolution of their dispute (see at < https://www.ontario.ca/laws/regulation/900194>).

${ }^{61}$ As seen from the discussion above, this presents a standard view of mediation intervention within the western model of mediation. It is often described as a process where a neutral third party assists parties to come to agreement. Whether the term is neutrality, impartiality or non-alignment, there is expected to be maintained a distance between the parties and the mediator.

62 Mediators participate in the mediatory process in a very active manner. They do so by assuming different personas at various times during the process. The mediator is not only the third party facilitator invited into the process; the mediator becomes a party negotiator and a party adviser as well. For example, in a two party dispute, the mediator takes on the following identities: that of his own self as third party facilitator when with both parties; that of one party when confronting the other or when empathizing with one party, and vice versa; and that of party adviser to each party; see De Girolamo, note 12 at 149-152 and 200205 for a fuller exposition. 
explaining as follows: "There may not, of course, be any really impartial spectator in the world, but we can persuade ourselves to look at the values and priorities that others have, and then examine them all with as much objectivity as we can bring into the exercise. Attempts at being objective can be helped by our putting on other people's hats - even their identities - and asking ourselves: how would our choices, our values look to them?"63 Sen requires this form of impartiality through the outsider's anti-parochial voice - the impartial spectator draws on the perspective of others and keeps parties' values under scrutiny. ${ }^{64}$ Through the mediator's evolving identity as party, advisor and third party facilitator, a certain objectivity is forced upon the parties.

Furthermore, the mediator may not be the only actor to provide the anti-parochial voice. The data also suggests that mediators view the legal representatives attending mediation as objective outsiders. ${ }^{65}$ In one case, the lack of counsel led to lack of resolution and therefore the opportunity to achieve justice, in whatever form: "Here there was a problem. The parties were extremely subjective of their position and there was no touchstone of objectivity, which lawyers provide. No touchstone of saying there are risks and cost consequences...Lawyers would work with the mediator and reinforce the message of the mediator. This wasn't here."66 Legal representatives can play a significant role in mediations. They are often present during the process. While many cannot see beyond their own contrived arguments, others provide a sounding board to their clients and become the voice of reason. ${ }^{67}$ The presence of these legal representatives arguably provides additional outsider voice.

\footnotetext{
63 Amartya Sen, "Values and Justice" (2012) 19(2) Journal of Economic Methodology 101 at 104. he presented to the claimant; the defendant solicitor on the other hand stood on the strength of his legal position, refusing to see weakness in it, evidencing a typical adversarial
} 
It is this concept of open impartiality together with public reasoning that comprise objective reasoning, the first requisite element of Sen's concept of justice. Having met the requirement of discursiveness and open impartiality, it would appear that the mediation process offers the opportunity for objective reasoning to occur in decision-making. The second requirement in Sen's theory of justice rational choice - must now be explored.

\section{(b) Rational Choice}

The decision must also reflect rational choice, the second element of Sen's theory. Sen describes rational choice as a choice based "on reasoning that we can reflectively sustain if we subject them to critical scrutiny."68 It exists where decision-makers have critically analysed their choices and the decision is supported by sustainable reason. ${ }^{69}$ Sen recognises too the diverse motivations behind decisions and the alternative choices available to individuals, all of which can be supported rationally. ${ }^{70}$ As a result, rational choice cannot be predicted..$^{71}$ However, as long as decisions can be justified, notwithstanding the motivations underlying them, the refusal of other alternative choices does not mean justice is lacking in the choice made. ${ }^{72}$ As Sen states: "...we have different types of competing reasons of justice, and it may be impossible to reject them all with the exception of just one set of complementary principles that cohere nicely and entirely with each other. Even when a person does have a clearly favourite priority, such priorities may vary from person to person, and it may be difficult for someone to reject altogether possibly well-defended reasons to which others give priority."73 Rational

\footnotetext{
stance in the mediation. It was rare in the mediations observed that counsel were not present. 68 Sen, note 1 at 180.

${ }^{69}$ Sen, note 1 at 180-181.

70 Sen, note 1 at 183, 187.

${ }^{71}$ Sen, note 1 at 183 .

72 Sen, note 1 at 200.

${ }^{73}$ Sen, note 1 at 200 .
} 
choice involves the prioritisation of values by the parties. As Sen says, people value things differently and accordingly there is more than one way to come to a decision.

Consider the Sen example of three children and their flute. All three have justification for wanting the flute and being given the flute: "Indeed, even entirely impartial judges, who are not moved by vested interest or by personal eccentricity, may see the force of several disparate reasons of justice in a case like this, and they may well end up differing from each other on what decisions should be taken, since the competing arguments all have some claim to impartial support."74 A valuation of what is important to a party must be undertaken. In mediation, this can be the need to be heard, the need to challenge, the need to be acknowledged, the need for vindication, or the need to be told by a decision-maker that a party is right. ${ }^{75}$ For example, in one mediation, an apology was the value sought rather than economic gratification. ${ }^{76}$ One reason may be as valid as another - the choice is personal.

Often, the choice is a financial one. Mediators commonly talk to the parties about making 'reasoned' offers and being able to explain the offers. ${ }^{77}$ This is about both the justification for and acceptance of an offer. In this regard, the data shows that parties in mediation seem to justify offers by relying on the existence of litigation risk. Parties are made to reflect on the litigation risk they face if they pursue their disputes through the courts including the uncertainty of litigation, the cost of litigation, and the time involved in litigation. For example: "We are saying here we have a very strong case. Yes, we could win. Yes, we could lose. It is not a cut and dry case. There is litigation risk. If they are thinking of a large amount of money, we will need to walk out. I don't have a large amount of money; it is all gone. To pay

\footnotetext{
${ }^{74}$ Sen, note 1 at 200.

75 Some words used by the parties in relation to what the process provides include, referring to the search for 'truth', 'right and wrong', 'satisfaction', 'fairness', 'vindication', 'finality/certainty', 'compassion', 'equity' or being 'owed' in relation to desired outcome. 76 For the claimant, an apology for improper medical care was more important than a damages payment: Case 13 at 13-25.

77 Mediator to defendant in Case 10 at 10-41.
} 
even the amount given is a struggle and I would need time to pay."78 For this party, rational choice in mediation required weighing litigation risk against the offer.

Parties have their personal motivations and alternative choices available to them in the pursuit of resolution. During mediation, the third party works with the parties to assist them with understanding their choices, many of which provide valid reasons why they would choose to either resolve their dispute at mediation or continue the dispute through to an adjudicative process. Choices at mediation are made in relation to what has been discussed throughout the process: parties analyse the options available to them $;^{79}$ they ensure that their position is clearly stated to the other party and to themselves; ${ }^{80}$ and they make decisions on the basis of a critical analysis of their alternatives. Decisions are also subject to critical analysis through mediator and legal representative participation. The elements of objective reasoning (as discussed in the previous section) provide the foundational underpinning of rational choice. As long as these decisions can be justified while recognising the pluralism of values that can be attributed to the decision, then rational choice would be realised.

\section{(c) Freedom of Choice}

The final of the three elements comprising Sen's theory of justice is freedom of choice. Freedom of choice is necessary for the realisation of rational choice, invoking two concepts: capability opportunities and fairness of process. ${ }^{81}$ Capability is the actual ability of people to choose: it focuses on the ability of the

\footnotetext{
78 The defendant is recognizing risk here in the face of what he believes is a strong case: Case 28 at 28-34.

${ }^{79} \mathrm{An}$ example is seen with the claimant solicitor going through the options with the client in Case 15 at 15-62.

${ }^{80}$ Recall one counsel saying he needs to discuss client wants and legal position: "I need to go through [this] so it's not palm tree justice - I am going through the building blocks".; see Case 21 at 21-16.

${ }^{81}$ Sen, note 1 at 232 and 296.
} 
individual to make use of the choices available to them. As Sen points out, a theoretical ability is no ability if it cannot be realised as a practical ability.

Capability is not the only factor in assessing justice however; there must be fairness in the process of choice, says Sen. Justice cannot be interested only with "overall opportunities and advantages of individuals in a society. The subject of fair process and a fair deal goes beyond individuals' overall advantages into other - especially procedural - concerns, and these concerns cannot be adequately addressed through concentrating only on capabilities." ${ }^{82}$ And further, "A theory of justice - or more generally an adequate theory of normative social choice - has to be alive to both the fairness of the processes involved and to the equity and efficiency of the substantive opportunities that people can enjoy."83 In other words, it is not only about the individual's ability to realise opportunities, it is also about the social process leading to the decision. Freedom of choice is about individual capability within a social construct.

(i) Capability

The importance of the freedom of choice element of Sen's theory and its connection to rational choice lies in the opportunity of an individual to pursue her goals: any decision must be as a result of a party's free choice. It is not sufficient that the individual attains his objective - it must come from his free choice. ${ }^{84}$ For example, a person does not have free choice if someone requires or demands her to choose a particular objective even if that objective is the desired objective because there would be no freedom in the process of that choice. ${ }^{85}$ Freedom of choice refers to the opportunity to take action and the ability to do so. To illustrate his point, Sen uses the example of two people who have stopped eating: one is a person fasting and the

\footnotetext{
82 Sen, note 1 at 297.

83 Sen, note 1 at 296.

84 Sen, note 1 at 228.

${ }^{85}$ Sen, note 1 at 229-230.
} 
other is a malnourished person. Both people are starving; one of his own accord, and the other through circumstance. Sen says that you cannot take the outcome of starving and say it is the same for both people because only one has made the choice to starve. ${ }^{86}$ The other has not and therefore does not have capability of action in the Sen sense. Justice lies in the opportunity of choice and the ability to choose. Essentially, this requirement appears to be about self-determination: the capability of an individual to make decisions and thus be able to choose their destiny rather than being given a destiny not of their choosing.

In addition to this quality of self-determination, Sen requires social perspective and public engagement for there to be true capability. Regarding social perspective, individuals decide on the basis of individual capacities, but are influenced by the values of and relations with society. ${ }^{87}$ As a result, capability is not linked only to individualism: society is connected to the execution of that individualism. Sen seems to be saying that society needs to play a role in the exercise of capability ${ }^{88}$ People do not make decisions in a vacuum: social influences impact individual decision-making. ${ }^{89}$

In applying this to mediation, it may be expected that a social perspective is lacking given the private nature of the process. On the contrary, the social and normative framework of mediation is very influential in parties' decision-making. De Girolamo in her study of legal culture, found:

[Mediation is] a dispute resolution process that allows parties to pursue their own personal pragmatic solution through a social process infused with legal under and overtones. Parties have the freedom to choose self-determination instead of imposed order, yet self-determination exists within a blended framework of social process and legal rules, norms and structures. ... The references to rules and the litigation process throughout the social exchange impact the actions and decisions

\footnotetext{
86 Sen, note 1 at 237.

87 Sen, note 1 at 245 .

88 Sen, note 34, "Ideas of justice: a reply" at 311.

${ }^{89}$ Sen, note 1 at 245.
} 
of the parties. They cannot avoid them nor do they practically avoid them for all their assertions that they are doing so. They work on the level of legal rules and structures: the law of the books and the structure of the adjudication process is a formidable presence in the discourse between these two parties. They are used to threaten, increase bargaining power or persuade: whatever the purpose, they exist and form a fundamental basis to the interaction of these parties. It is not social interaction alone that leads to resolution: it is law with all its trappings through the guise of social interaction. The social interaction at the heart of negotiated order is achieved through invocation of legal rules, norms and structures. ...law permeates every level of the social interaction that occurs. It compels action, it constrains action and it determines outcome despite its non-adjudicatory nature. Social and legal interaction provides the source of legal culture: it is law as it impacts conduct of everyday life. ${ }^{90}$

It is the convergence of rules, norms, structures and process that connects the individual to the social in mediation. ${ }^{91}$ Societal institutional values of law impact the process: individuals make decisions in the face of the legal values espoused by the society in which they live. Their act of self-determination is guided by social influences they are subjected to.

While Sen requires social perspective, Sen is against a view that encapsulates only society's view of what is good and just. The freedom of choice element of Sen's theory recognises that decisions are made within a context of social influences while focusing on individual capability. The individual must participate and determine what is good for themselves. However, to protect against a subjective view of the justice experience, capability also requires public engagement. Individuals sometimes cannot see beyond their state - they accept their fate and live with it. ${ }^{92}$ Public engagement assists individuals to move beyond a restricted view of their capabilities by engaging in objective reasoning and experiencing the open impartiality of outsiders. ${ }^{93}$ Objective reasoning then becomes inextricably linked to capability through the concept of public engagement, which occurs through its elements.

\footnotetext{
90 De Girolamo, note 30 at 143-4.

91 See earlier discussion at note 30 .

92 Sen, note 1 at 274-275.

${ }^{93}$ Sen, note 1 at 245 . See also discussion at note 34 .
} 
In mediation, do the parties who accept the terms of an agreement they have negotiated see beyond a self-reflexive and limited worldview of their position in coming to their decision? Recall from the earlier discussion that the mediator's interactions within the process are multi-dimensional: the mediator becomes the anti-parochial voice as discussed earlier. This is realised when the mediator takes an active role in the process, taking on several identities during the course of the mediation, evolving from party voice, party advisor voice and third party facilitator voice. ${ }^{94}$ Arguably, this fact of the mediator as an active participant, taking on the role of the third party intervener, party and party advisor represents Sen's societal voice and, together with the social influence of normative values on decisionmaking, help establish social perspective and public engagement in the process of free choice.

Turning now to the concept of self-determination as a feature of capability, mediation appears to offer freedom of choice in the party's movement toward resolution. Arguably, parties have the freedom of choice with respect to both process and outcome. Mediation is voluntary and parties are invited to the table they are not coerced into engaging fully in the process. ${ }^{95}$ Furthermore, it is a process steeped in the philosophy of self-determination where parties are actualising a choice by first participating in the mediation process and second by determining whether to resolve their dispute. ${ }^{96}$

\footnotetext{
94 De Girolamo, notes 12 \& 62.

95 The discussion in this paper and its data take place in the context of a non-mandatory mediation process and therefore the participation in terms of the process is voluntary. However, even in a mandatory scheme, parties are not compelled to remain at the table or to engage in earnest dialogue about resolution. Mandatory schemes can lead parties to the table, but cannot force the parties to participate to agreement. Freedom of choice still exists for them regarding all elements of resolution including how they get to resolution and what they choose.

96 This concept of self-determination is seen as a fundamental tenet of the mediation process: see for example, Kimberlee K. Kovach, "The Mediation Coma: Purposeful Or Problematic" (2015) 16 Cardozo J. Conflict Resol. 755 at 773; Jacqueline Nolan-Haley, "Mediation: The Best And Worst Of Times" (2015) 16 Cardozo J. Conflict Resol. 731 at 737.
} 
This self-determinative nature of mediation seems to satisfy Sen's capability requirement. However, when we look at the data of the actors' experiences, we see that capability is not straightforward. In one mediation, for example, the mediator was of the view there was no justice in the agreement and that the settlement was "not the best or fairest settlement he ever saw" because he felt that there was a power imbalance favouring one party over another with the stronger party taking advantage of a mistake made by the other party. ${ }^{97}$ For this mediator, there was no real capability in reaching the outcome. In another case, a claimant accepted a settlement because the costs of litigation were too great. For this claimant, "I am walking away with less today than if I fight for what I know is right in a year."98 He also says that he was "outmaneuvered' by the Defendant.99 The lack of capability may not always be so overtly observed, however. In one case involving an insurance company seeking repayment of monies paid under a policy of insurance from the widower of an insured, sympathy for the widower appeared to impact decisionmaking, resulting in a favourable outcome for the widower. ${ }^{100}$

Capability may not always present even though the outcome is self-determinative. The ability of mediation to meet the element of capability in Sen's theory of justice runs into difficulty when the self-determinative nature of mediation and the ability of the parties to choose freely becomes stymied due to factors at play during the process, such as economic, cultural, legal or emotional power, where such power or

\footnotetext{
97 Mediator interview, Case 12 at 12-102 and 105. The case involved two insurance companies and the calculation of fees. A mistake was alleged in the drafting of the documents; it was clear there was a mistake, but the party took advantage of the wording of the contract.

98 Claimant in Case 32 at 32-44.

${ }^{99}$ Claimant in Case 32 at 32-65.

100 Case 27: In this case, the widower had spent the monies from the estate of his partner. The insurance company wanted repayment of monies inappropriately and mistakenly paid to the insured. The defendant solicitor recognised the power of sympathy - that although the law was on its side, a sympathetic judge would find in the widower's favour even if it would be difficult to do so. The claimant also acknowledged the sympathy card in saying to the mediator on settlement: "There was a lot of sympathy in the room and I hope the defendant appreciates it." See at 27-50. Yet, despite the recognition of the impact of sympathy, the claimant acknowledged it got what it wanted.
} 
lack thereof influences choice. As the data suggests, these types of factors can put into question the ability of parties to choose an outcome.

Some might argue, however, that a decision made in the face of the exertion of economic, cultural, legal or emotional power, for example, during the course of the process may still be recognised as a justifiable rational decision. Freedom of choice may continue to be realised through rational choice in that the rational choice has recognised the limitations to the opportunities available due to such factors in the choice made. This raises the question whether something can be a rational choice on the one hand, but not a free choice, on the other. According to Sen, the decision may be the outcome of rational choice, but a rational choice may not necessarily be a free choice where the element of true capability is missing. Capability is needed within the rational choice that is made. Without it, there would be no justice in the choice. In mediation, the ability to exercise freedom of choice by a party in decisionmaking may be restricted as a result of the exercise of actual or perceived power by the other. ${ }^{101}$ As a result, it is in this aspect of capability, or the lack thereof, that may create a barrier to attaining a substantive form of justice in mediation.

(ii) Fairness of Process

101 The issue of power imbalances and their impact on the mediation process is not new. However, these power imbalances also exist in the litigation process. See Marc S. Galanter, "Why the Haves Come out Ahead: Speculations on the Limits of Legal Change" (1974) 9 Law and Society Review 95 and Marc S. Galanter, "Reading the Landscape of Disputes: What We Know and Don't Know (and Think We Know) about Our Allegedly Contentious and Litigious Society" (1983) 31 UCLA Law Rev. 4. For the mediation process, the issue is connected to the function of the mediator: questions whether a mediator should take steps to correct such imbalances or similarly, ensure fairness in resolution are issues that come up in the literature. In the framework of mediators being required to be or seen to be neutral, impartial and independent, mediators are not expected nor encouraged to realign such imbalances. See for example, Colleen M. Hanycz, "Through the Looking Glass: Mediator Conceptions of Philosophy, Process and Power" (2004-05) 42 Alberta L. Rev. 819; Omer Shapira, "Conceptions and Perceptions of Fairness in Mediation" (2012) 54 S. Tex. L. Rev. 281; Susan Nauss Exon, "How Can a Mediator Be Both Impartial and Fair?: Why Ethical Standards of Conduct Create Chaos for Mediators" [2006] J. Disp. Resol. 387; Susan Oberman, "Mediation Theory vs. Practice: What Are We Really Doing? Re-Solving a Professional Conundrum" (2005) 20 Ohio St. J. on Disp. Resol. 775. 
Freedom of choice is not only about capability; it is also about fairness of process. It must be reflected in both process (fairness of process) and outcome (the result of capability). In this regard, Sen is interested in the comprehensive outcome that is reached as opposed to a culmination outcome. Comprehensive outcomes are concerned about the process leading to the achievement of the outcome as well as the outcome itself whereas culmination outcome is concerned solely with the outcome obtained, without regard to process. ${ }^{102}$ Sen says: “...the idea of freedom also respects our being free to determine what we want, what we value and ultimately what we decide to choose. The concept of capability is thus linked closely with the opportunity aspect of freedom, seen in terms of 'comprehensive' opportunities, and not just focusing on what happens at 'culmination"'. 103 In other words, there is a need for a proper process underlying decision-making: justice is not only about the decision; it is also about how you come to the decision.

Turning to his use of the word 'freedom', the concern for Sen at a micro level of analysis appears to be the need for the individual not to be constrained in his or her choice in any way - there must be liberty of action in the choice that is made. It is a true liberty that Sen seeks: one that frees the individual from any impediment toward realising rational choice. ${ }^{104}$ Sen speaks of fairness of process in relation to the advantages that individuals have and the opportunity for them to realise these advantages. The specific nature of fairness of process in its relationship with capability, however, is unclear: Sen speaks of equity and efficiency on one hand, and fairness of process generally on the other. ${ }^{105}$ Fairness of process can arguably be seen as a composite of the other elements of Sen's theory of justice: full participation in the decision-making process, open communication among all players, the existence of rational choice, and real capability (with its attendant

\footnotetext{
102 Sen, note 1 at 230.

103 Sen, note 1 at 232 .

104 For example, power over individuals forcing them to a particular choice would not be a fair process as the individual would not be exercising free choice: Sen, note 1 at 298-317. 105 Sen, note 1 at 296.
} 
elements of opportunity to choose, social perspective and public engagement) in the exercise and realisation of rational choice. A fair process is one, therefore, where rational choice is exercised through capability, and objective reasoning supports decision-making. Any process which prevents the actualisation of rational choice, after a process of objective reasoning, is a flawed process. There must be no barriers to the progression to and exercise of rational choice for freedom of choice to be realised, and with it, fairness of process. From the Sen perspective, this concept of fairness of process appears to be the foundation of a building block: it is what ensures the other elements are present for justice. It allows capability to be exercised through objective reasoning and rational choice.

Fairness of process in mediation is manifested in the dispute resolution literature by the phrase procedural justice. Elements of procedural justice are said to include a need and desire for an opportunity by parties to tell their story and to control its telling, consideration of their story in a fair manner by the mediator, and to be treated with dignity and respect. ${ }^{106}$ Procedural justice is also seen as including concepts of equal access and treatment as well as the neutrality or impartiality of the third party intervener. ${ }^{107}$ Parties, in essence, want to be treated fairly and be given the opportunity to be heard. In the mediation literature, there seems to be some consensus that this is one area in which mediation excels - that mediation provides procedural justice, if nothing else. ${ }^{108}$ Indeed, parties to the process speak in terms of such elements of procedural justice. For example, one mediator tells the parties: "I honestly can say I do not take sides; ...these are all individuals with their own agendas, much are valid and need to be respected; I do not think of when I will get the next mediation from the defendant but to treat each with equality."109

\footnotetext{
106 Nancy A Welsh, "Making Deals in Court-Connected Mediation: What's Justice got to do with It?" (2001) 79 Wash. U. L. Q. 787 at 792.

107 Jonathan M. Hyman \& Lela P. Love, "If Portia were a Mediator: An Inquiry into Justice in Mediation" (2002) 9 Clinical L. Rev. 157 at 192.

108 See for example, Rebecca Hollander-Blumoff \& Tom R. Tyler, "Procedural Justice in Negotiation: Procedural Fairness, Outcome Acceptance, and Integrative Potential" (2008) 33 Law \& Social Inquiry 473. See also, Welsh, note 106.

${ }^{109}$ Mediator to claimant in Case 13 at 13-18.
} 
Further he says that the process needs to be treated with pride and respect. ${ }^{110}$ For parties in another mediation, the process was necessary for resolution: "to be brutally honest, I think we could not get there without it".111 The claimant in the same case said that the process was 'effective; it was easy', and another defendant representative said that the process was good. ${ }^{112}$ Important for another actor in the process was the ability to participate in the process: "I find mediation better than the court process because at least I can say something. I just had to sit through it [court]."113 His solicitor also added: "You feel disempowered. Mediators are trained to deal with this.... It is important that people do not think they are part of a grinding process." 114 A mediator in another case likens the process to a day in court telling a party that "it is your day in court."115

For these actors of the mediation process, a concept of procedural justice seems to relate to purely procedural aspects of the process: being heard and treated with respect; receiving assistance from a perceived third party neutral; and being given the opportunity to participate fully in the process and reach resolution. The reference to a party's 'day in court' is a common one, evoking the positivist view of a just arena. Mediators imply by their words, a process which is similar to a juridical process, as if to strengthen the value of the mediation process itself, and suggesting a congruency in outcomes. What a court provides, mediation also provides. Implicit in this, is a suggestion that a just process leads to a just outcome.

This concept of procedural justice is further assisted by the presence of legal counsel at the mediation, which also emphasises a congruency with court proceedings. Legal counsel ensure their clients are not procedurally bullied. In one mediation, the solicitor was late and the unrepresented party agreed to begin the

\footnotetext{
110 Mediator to claimant in Case 13 at 13-25.

111 Representative in Case 12 at 12-96.

112 Case 12 at 12-96.

113 Appellant to the mediator in Case $1 \mathrm{a}$ at $1 \mathrm{a}-46$.

${ }^{114}$ Appellant's solicitor to appellant in Case $1 \mathrm{a}$ at $1 \mathrm{a}-46$.

115 Mediator to claimant in Case 32 at 32-9.
} 
process without its solicitor. The opposing counsel proceeded to cross-examine the party: the party was not protected from a grilling. The mediator in the case wondered if he should have let it happen. ${ }^{116}$ Counsel protect their clients and ensure procedural fairness to the extent it is within their control. For the mediator: "Mediation is fair when both have legal advice. My concern is when the government pushes it and parties do not have legal advice."117

The issue of fairness of process is not a neat and tidy one, however. Several issues arise in mediation that can tip the balance away from fairness such as factors of economic, cultural, legal and emotional power, mediator tactics, the private nature of mediation and the lack of institutional safeguards. For example, not all experience a positive process. In one case, a defendant solicitor commented that the claimant was not at the mediation in good faith. ${ }^{118}$ Another party who came to agreement felt bullied by the other side: "Every trick is being played here to knock me down. ...I am being done."119 A similar feeling is expressed by another claimant: "I am feeling beaten up."120 Comments such as these seem to be suggestive of the close connection between Sen's requirement for capability of choice and fairness of process. They seem to articulate a frustration parties can feel when they do not get what they want or are stymied in their ability to choose. It would seem that where there is capability within the exercise of rational choice, there is fairness of process; where there is a lack of capability or sustained reasoning underlying a choice made, fairness of process is undermined and with it, freedom of choice. In such circumstances, the requisite element of freedom of choice is vulnerable to attack, and with it, the sustainability of the presence of justice in the outcome.

\footnotetext{
116 This occurred in Case 1a. Although the appellant had consented to begin the mediation without his solicitor present, it became clear in the mediation that the opposing barrister took advantage of this to examine the appellant in a manner that was suggestive of a courtroom. The mediator did not prevent the examination.

117 Mediator to appellant in Case 1a at 1a-47.

118 Defendant solicitor to mediator in Case 10 at 10-55.

119 Claimant to mediator in Case 7 at 7-59.

120 Claimant to mediator in Case 14 at 14-80.
} 


\section{Conclusion}

Sen's theory of justice is a comparative one of alternatives - people must make decisions from the choices they have available to them. ${ }^{121}$ For Sen, the reality of life needs to form part of the 'justice' conundrum and as such, it is a practical idea of justice he offers. ${ }^{122}$ Ideal justice is not possible, according to Sen. As a result, to achieve justice, we must work with what we have through a comparative theory where alternatives are available and choices are determined on the basis of objective reasoning, rational choice and freedom of choice. ${ }^{123}$ For Sen, the goal for any process should be the enhancement of substantive justice rather than the search for the unattainable in the form of ideal justice.

We can see that the elements of Sen's theory are interwoven: they are not only dependent on each other to form the whole, but they are intrinsically linked to one another. Objective reasoning requires debate and impartiality, essentially public engagement as he later describes; ${ }^{124}$ rational choice requires scrutiny and justification, ostensibly coming from the process of objective reasoning; and freedom of choice requires ability to make use of opportunities and fairness of process in the rational choice that is made, embodying both an individual and social perspective.125 Together, they form for Sen a theory of justice.

Mediation in its current form falls short of achieving just outcomes. The weakness rests with the last of Sen's three elements, freedom of choice. This, however, is not an insurmountable problem as that presented by a positivist view of justice. The need for the impartial decision-maker in an open forum sanctioned by state laws prohibits mediation from ever delivering justice, according to the positivist frame.

\footnotetext{
${ }^{121}$ Sen, note 34, "Ideas of justice: a reply" at 310.

122 Sen, note 34, "Ideas of justice: a reply"; Sen, note 21, "Symposium on the Idea of Justice: A Reply" at 319.

123 Sen, note 21, "Symposium on the Idea of Justice: A Reply" at 321-324.

124 Sen, note 1 at 245.

125 Sen, note 1 at 296, 297 and 245.
} 
By moving away from this restrictive frame and applying Sen's theory of justice, the opportunity for mediation to offer a substantive form of justice is made possible. Justice within the pluralistic, expansive view of substantive justice conceived by Sen is attainable through a private dispute resolution process such as mediation. More work needs to be done, however, to achieve this goal. The exploration in this paper provides the first step to recognising what is possible for mediation and its delivery of justice.

In summary, objective reasoning, the first of Sen's three elements underpinning his theory of justice, appears to have been made out: there is dialogue, interaction, debate and reflection in the mediation process; and while the issue of impartiality is not as clear, mediation offers the Sen conceptualisation of impartiality as antiparochial voice. As for the second element of rational choice, this too appears to be evident in mediation. As long as decisions can be justified through scrutiny, critical analysis and sustainable reasons, a rational choice can be made. Through the active role of all actors to the process, including the social interaction that occurs, the challenges that are made, the parties' understanding of the choices they face, and the reasoned decisions that are made as a result, rational choice in decision-making is possible.

It needs to be stressed however that this achievement of the first two elements of Sen's theory occurs as a result of the nature of the mediation process and the active role of mediators in ensuring objective reasoning and rational choice occurs. In this regard, there needs a recognition that mediators are more than mere facilitators: they provide the anti-parochial voice through their fugitive identity as party, party advisor and third party intervener. For proponents of mediation to continue to advocate mediation as offering justice, this needs to be addressed as a dominant feature of the mediation process. In so doing, the first two elements of Sen's theory would be well met. In view of the reality of the process as evidenced by ethnographic data, there should be no barrier in this regard. 
It is with the last of the three elements of Sen's theory of justice that mediation may run into substantive difficulty. Freedom of choice is vulnerable to attack both in terms of capability and fairness of process.

Turning first to capability, while it appears that the social perspective embedded within capability is evident, the individual element of parties realising actual ability of choice is vulnerable. For example, any power imbalance, arising from actual or perceived factors such as those described earlier, existing between parties would serve to lessen the element of freedom of choice in mediation as it would impact the process and outcome. For proponents of the process, if they are to argue that justice can be obtained through mediation, barriers to freedom of choice such as the presence of power imbalances must be dealt with. This is not easily resolved by the dispute resolution literature due to the conflicting views about the appropriateness of the mediator to actively redress issues of power arising during the process. This debate needs to come to the fore and steps taken to recognise the impact of such barriers on the realisation of justice in the process. The difficulty is not insurmountable, however. It is something that can be addressed with a consideration of the mediator's actions during the process and a determination of what actions are necessary to ensure the elements of freedom of choice are satisfied.

As for fairness of process, this seems to be intertwined with the capability issue as discussed earlier: where capability exists and the other elements made out, fairness of process is less likely to be an issue; however, where they do not exist, fairness of process will likely be missing. The focus therefore should be on ensuring freedom of choice through the existence of a real ability to choose the offered rational choice.

This exploration of the possibility of attaining justice in mediation moves away from a restricted concept of justice to Sen's expansive, plural view that incorporates both individual and societal values. It gives mediation the chance to prove to its detractors as well as its proponents that a substantive form of justice can be sought through its process. This review indicates that justice is possible, but work needs to 
be done to achieve it. Mediation theory and its attendant practice should be revisited. The revisitation should encompass the actions that a mediator needs to take to ensure that the requirements of Sen's objective reasoning, rational choice and freedom of choice have been satisfied during the mediation process, and ultimately, justice achieved. 